\title{
Short- and long-term effects of forage supplementation of calves during the preweaning period on performance, reproduction, and milk yield at first lactation
}

\author{
LI. Castells, ${ }^{*}$ A. Bach, ${ }^{*} \dagger$ and M. Terré ${ }^{* 1}$ \\ *Department of Ruminant Production, IRTA (Institut de Recerca i Tecnologia Agroalimentàries), 08140 Caldes de Montbui, Spain \\ †ICREA (Institució Catalana de Recerca i Estudis Avançats), 08010 Barcelona, Spain
}

\begin{abstract}
Sixty female Holstein calves [body weight $(\mathrm{BW})=$ $39.5 \pm 3.76 \mathrm{~kg}]$ were fed a ground starter concentrate [19\% crude protein, $19 \%$ neutral detergent fiber (NDF)] during the preweaning period. Furthermore, oats hay (68\% NDF) was supplemented only during the postweaning period $(\mathrm{CON})$ or during both pre- and postweaning periods $(\mathrm{OH})$ to evaluate performance until first breeding, diet digestibility after weaning, reproductive performance, and milk yield at first lactation. Calves were individually housed and bedded with wood shavings. All calves were offered $6 \mathrm{~L} / \mathrm{d}$ of milk replacer (MR) at $12 \%$ dry matter (DM) in 2 feedings until $28 \mathrm{~d}$ of age, $3 \mathrm{~L} / \mathrm{d}$ of $\mathrm{MR}$ at $12 \% \mathrm{DM}$ in 2 feedings from 29 to $44 \mathrm{~d}$ of age calves, and $1.5 \mathrm{~L}$ of $\mathrm{MR}$ at $12 \% \mathrm{DM}$ in 1 feeding from 45 to $51 \mathrm{~d}$ of age. Animals were weaned at $52 \mathrm{~d}$ of age. Starter concentrate and forage intake were recorded daily and BW weekly until $65 \mathrm{~d}$ of age. Two weeks after weaning, total-tract apparent digestibility was determined in 6 calves per treatment. Heifer BW was recorded at 10 mo of age. Breeding and milk yield at first lactation were also recorded. Starter concentrate intake was greater in $\mathrm{OH}$ compared with $\mathrm{CON}$ animals during the preweaning period. As a result, calves in the $\mathrm{OH}$ treatment had greater average daily gain (ADG) than $\mathrm{CON}$ animals during the preweaning period. After weaning, $\mathrm{OH}$ calves consumed more forage than $\mathrm{CON}$ animals, but we found no differences between treatments in ADG and starter concentrate intake. Similarly, total-tract apparent digestibility did not differ between treatments, and BW and ADG from 2 wk after weaning to 10 mo of age did not differ between treatments. Moreover, no differences in reproductive performance [age at first artificial insemination (AI), age at fertile insemination, conception rate at first AI, and number of $\mathrm{AI}$ ] or milk yield at first lactation were observed between treatments, although a positive re-
\end{abstract}

Received October 28, 2014.

Accepted March 22, 2015.

${ }^{1}$ Corresponding author: marta.terre@irta.cat lationship between growth rate early in life and future energy-corrected milk yield was found. We conclude that offering forage to young calves early in life allows improvements in growth before weaning and could help in the transition to mixed diets, but the improvement in growth achieved early in life was not maintained at 10 mo of age.

Key words: forage, growth, heifer

\section{INTRODUCTION}

The 2 most important goals for dairy producers regarding heifer rearing are (1) reducing age at first calving to diminish the net cost of raising replacement heifers (Tozer and Heinrichs, 2001) without impairing BW at calving to optimize milk yield at first lactation (Bach and Ahedo 2008), and (2) ensuring high milk yield at adulthood. Age at first calving (AFC) depends on age at first insemination and fertility, but deciding to inseminate heifers earlier to decrease AFC without considering their musculoskeletal development may negatively affect milk production at first lactation (Mohd Nor et al., 2013). Although decisions to start inseminating heifers should be based on BW or skeletal measurements (Le Cozler et al., 2008), in a survey done in the Netherlands, $60 \%$ of farmers indicated that they used age alone to determine the moment of first insemination (Mohd Nor et al., 2013).

Greater growth during the first 6 mo of life on UK farms has been associated with lower AFC (Brickell et al., 2009), and several studies (Moallem et al., 2010; Bach, 2012; Soberon et al., 2012) have reported that improved performance during the preweaning period can result in greater milk yield at first lactation. During the preweaning period, ADG can be improved by feeding high levels of milk or milk replacer (MR) to calves (Terré et al., 2007; Raeth-Knight et al., 2009), but the supplementation of forage in diets at low levels of MR also resulted in improved performance during this period (Castells et al., 2012). Therefore, some benefits of forage supplementation early in life may be envisaged later in life due to improved growth rate at a young 
age. The objective of the present study was to evaluate whether the expected improved performance early in life resulting from supplementing forage to young calves fed low volumes of MR has longer-term effects, potentially affecting reproductive performance, growth until 10 mo of age, and milk yield at first lactation.

\section{MATERIALS AND METHODS}

\section{Animals and Treatments}

Sixty female Holstein calves (initial BW $39.5 \pm 3.76$ $\mathrm{kg}$ and $6.7 \pm 2.12 \mathrm{~d}$ of age) were individually housed in the facilities of the contract heifer operation Recria Segle XXI (Vilanant, Spain). Calves were randomly assigned to 1 of 2 dietary treatments according to age and BW. Dietary treatments consisted of a ground starter concentrate (Table 1) without any forage supplementation during the preweaning period and chopped oats hay $(8 \% \mathrm{CP}, 68 \% \mathrm{NDF})$ supplementation after weaning (CON), or the same starter concentrate plus supplementation of oats hay during the pre- and postweaning periods $(\mathbf{O H})$. Forage was chopped using a forage chopper (Seko, Curtalo, Italy) to the following particle size distribution: $27.5 \%>20 \mathrm{~mm}, 26.2 \% 8-20 \mathrm{~mm}$, and $46.2 \%<8 \mathrm{~mm}$. Water was offered ad libitum throughout the study. Calves received $6 \mathrm{~L} / \mathrm{d}$ of MR $(23.7 \% \mathrm{CP}$ and $20.1 \%$ fat; Celtilait, Ploudaniel, France) at $12 \%$ DM in 2 feedings until $28 \mathrm{~d}$ of age. From 29 to $44 \mathrm{~d}$ of age, calves were fed $3 \mathrm{~L} / \mathrm{d}$ of $\mathrm{MR}$ at $12 \% \mathrm{DM}$ in 2 feedings, and from d 45 to 51 , calves were fed 1.5 $\mathrm{L} / \mathrm{d}$ of $\mathrm{MR}$ at $12 \% \mathrm{DM}$ in one feeding. Animals were weaned at $52 \mathrm{~d}$ of age. Calves were kept in individual pens until 2 wk after weaning; thereafter, animals were housed in groups of 30 to 40 animals per pen. From 2 wk after weaning to 3 mo of age, heifers were fed the same concentrate feed as during the pre- and postweaning periods plus forage, both offered ad libitum. From 3 mo of age to calving, heifers were fed a TMR based on triticale silage and concentrate. From 3 to 14 mo of age, the TMR contained $15.0 \% \mathrm{CP}$ and $2.60 \mathrm{Mcal}$ of $\mathrm{ME} / \mathrm{kg}$ on a DM basis; from 15 mo of age to calving, the TMR contained $14.0 \% \mathrm{CP}$ and $2.40 \mathrm{Mcal}$ of ME/ $\mathrm{kg}$ on a DM basis. Hip height was measured at 13.5 mo of age and those heifers with hip height $>130 \mathrm{~cm}$ were inseminated when observed in estrus. Furthermore, heifers that were not observed in estrus at 13.8 mo of age were synchronized using a progesterone-releasing intravaginal device.

\section{Measurements and Chemical Analysis}

Starter concentrate and forage intake were recorded daily and BW weekly until $65 \mathrm{~d}$ of age. Later, at $10 \mathrm{mo}$ of age, BW was also recorded. Two weeks after weaning, total-tract apparent digestibility was determined in 6 calves per treatment following the method used by Castells et al. (2012). During 5 consecutive days, all feces were collected using plastic bags. Feces were weighed daily, and a $30 \%$ subsample was collected and dried at $60^{\circ} \mathrm{C}$. Fecal samples were composite by each animal and analyzed for DM, CP, NDF, and ash. Furthermore, veterinary treatments during the preweaning period, breeding data (age at first AI, age at fertile insemination, and total number of AI per gestation), and milk yield at 305 DIM were also recorded.

Samples of MR, starter concentrate, and feces were analyzed for DM $\left(24 \mathrm{~h}\right.$ at $\left.103^{\circ} \mathrm{C}\right)$, ash $\left(4 \mathrm{~h}\right.$ at $\left.550^{\circ} \mathrm{C}\right)$, and $\mathrm{N}$ content using the AOAC (1990; method no 988.05) adapted for an automatic distiller Kjeldahl (Kjeltec Auto 1030 Analyzer, Tecator, Höganäs, Sweden) and using $\mathrm{CuSO}_{4} / \mathrm{Se}$ as a catalyst instead of $\mathrm{CuSO}_{4} / \mathrm{TiO}_{2}$, $\mathrm{NDF}$, and ADF, with sodium sulfite and heat-stable a-amylase (Van Soest et al., 1991).

\section{Statistical Analysis}

Calf performance data were split into the preweaning period (from 10 to $51 \mathrm{~d}$ of age) and the postweaning period (from 52 to $65 \mathrm{~d}$ of age) and were analyzed using a mixed-effects model with repeated measures with the auto-regressive variance-covariance structure. The

Table 1. Ingredient and chemical composition (as \% of DM) of experimental starter feed and forages

\begin{tabular}{lc}
\hline Item & Value \\
\hline Ingredient & \\
Corn meal & 41.9 \\
Barley meal & 19.0 \\
Soybean meal, 44\% CP & 19.2 \\
Soybean hulls & 6.2 \\
Gluten feed & 2.8 \\
Sunflower meal & 4.4 \\
Carob & 4.0 \\
Palm oil & 0.3 \\
Premix 1 & 0.5 \\
Calcium carbonate & 1.0 \\
Sodium carbonate & 0.3 \\
Magnesium oxide & 0.2 \\
Sodium chloride & 0.2 \\
Chemical composition & \\
CP & 18.8 \\
NDF & 18.9 \\
ADF & 9.5 \\
Ether extract & 3.9 \\
Ash & 5.2 \\
\hline
\end{tabular}

${ }^{1}$ Mineral and vitamin composition: vitamin A 2,000,000 IU $/ \mathrm{kg}$, vitamin $\mathrm{D}_{3} 200,000 \mathrm{IU} / \mathrm{kg}$, vitamin $\mathrm{E} 7,500 \mathrm{mg} / \mathrm{kg}$, vitamin $\mathrm{B}_{1} 500 \mathrm{mg} /$ $\mathrm{kg}$, vitamin $\mathrm{B}_{2} 255 \mathrm{mg} / \mathrm{kg}$, vitamin $\mathrm{B}_{6} 147 \mathrm{mg} / \mathrm{kg}$, vitamin $\mathrm{B}_{3} 1.237 .5$ $\mathrm{mg} / \mathrm{kg}$, choline $17,980 \mathrm{mg} / \mathrm{kg}$, ferrous sulfate $7,515 \mathrm{mg} / \mathrm{kg}$, zinc oxide $10,000 \mathrm{mg} / \mathrm{kg}$, cupric sulfate $2,510 \mathrm{mg} / \mathrm{kg}$, manganese oxide 12,500 $\mathrm{mg} / \mathrm{kg}$, cobalt $100 \mathrm{mg} / \mathrm{kg}$, potassium iodide $105 \mathrm{mg} / \mathrm{kg}$, sodium selenite $50 \mathrm{mg} / \mathrm{kg}$, and magnesium oxide $40,000 \mathrm{mg} / \mathrm{kg}$. 
model included treatment, week of study, and their interaction as fixed effects, and the animal as random effect. Initial age and BW were split in 3 blocks; they were included in the model as a block, and if found not significant, they were removed from the statistical model. Due to the lack of normality, data from starter feed, forage, and total DM intake (TDMI) were rootsquare transformed. Least squares means and standard errors of the mean presented herein for these 3 parameters correspond to nontransformed data, and $P$-values correspond to the results from the mixed-effects model using root-square transformed data.

Veterinary treatments applied during the preweaning period and conception rate at first service and culling rate during first lactation were analyzed using a binary logistic regression including treatment as fixed effect. Feed digestibility, BW at 10 mo of age, breeding data, and milk yield at 305 DIM were analyzed with an ANOVA with treatment as main effect; ECM was calculated as follows:

$$
\text { ECM at } 305 \text { DIM }(\mathrm{kg})=\text { total milk yield }
$$

at $305 \mathrm{DIM} \times[(0.383 \times \%$ fat $)+(0.242 \times \%$ protein $)$

$$
+0.7832] / 3.1138 \text {. }
$$

Then, a linear regression model was fitted between ADG from 17 to $65 \mathrm{~d}$ of age, and first-lactation ECM yield at 305 DIM.

\section{RESULTS AND DISCUSSION}

\section{Performance}

During the preweaning period, concentrate intake was $20 \%$ greater $(P<0.05)$ in $\mathrm{OH}$ animals than in $\mathrm{CON}$ animals (Table 2, Figure 1). Furthermore, the interaction of TDMI with time indicated that TDMI was also greater $(P<0.01)$ in $\mathrm{OH}$ compared with $\mathrm{CON}$ animals (Table 2). This increase in TDMI was observed from 31 $\mathrm{d}$ of age to weaning. At $31 \mathrm{~d}$ of age, the amount of MR offered started to decrease, and therefore differences in TDMI were more dependent on concentrate and forage intakes, which were offered ad libitum, and were thus responsible for the differences between treatments on TDMI. The greater feed intake observed in $\mathrm{OH}$ calves resulted in $24 \%$ more $(P<0.01)$ growth in $\mathrm{OH}$ than in CON animals during the preweaning period, without affecting the gain-to-feed ratio. Furthermore, feed consumption, expressed as a percentage of BW, was greater $(P<0.01)$ in $\mathrm{OH}$ compared with $\mathrm{CON}$ calves. Improvements in concentrate intake, TDMI, and ADG during the preweaning period agreed with the results reported by Thomas and Hinks (1982) and Castells et al. (2012), who reported an increase in feed intake and ADG when straw was made available to young calves offered a pelleted ration. Although Khan et al. (2011) also reported an increase in TDMI of calves when grass hay was offered in the diet, no differences in ADG were observed. Terré et al. (2013) and Castells et al. (2013) found an increase in rumen $\mathrm{pH}$ when a forage source was included in the diet of young calves, suggesting that the increase in rumen $\mathrm{pH}$ may stimulate calves to consume more starter concentrate. We detected no differences in the number of veterinary treatments applied to the calves during the preweaning period in the present study (data not shown).

After weaning, once $\mathrm{CON}$ calves received forage in the diet, differences in concentrate intake, TDMI, ADG, and gain-to-feed ratio between treatments disappeared (Table 2). The only difference observed after weaning was in forage intake: $\mathrm{OH}$ animals consumed more $(P<$ 0.01) forage than CON animals (Figure 1). Two weeks after weaning, calves in $\mathrm{OH}$ treatment weighed $4 \mathrm{~kg}$ more $(P<0.05)$ than those in the CON treatment. After weaning, no differences in performance were observed because all calves in the present study had access to forage. In contrast, Castells et al. (2012) and Terré et al. (2013) observed differences in performance and feed intake after weaning when calves remained on preweaning diets, some of which had no forage included. Miller-Cushon and DeVries (2011) demonstrated that exposure to different solid feeds (concentrate or hay) during the milk-feeding stage influenced sorting behavior after weaning, and those calves offered concentrate during the preweaning period sorted for similar feed components when offered a mixed ration. We expected a lower $(P<0.05)$ percentage of forage intake in CON compared with $\mathrm{OH}$ calves in the present study because forage was a novel feed for CON animals. The consumption of forage, expressed as a percentage of TDMI, was, in CON calves (Table 2), similar to that reported by Castells et al. (2013) and Terré et al. (2013). In previous studies, these percentages of forage consumption were sufficient to foster an important increase in concentrate intake compared with intakes from calves fed no forage. Thus, it was also probably sufficient for CON calves in the current study to increase concentrate intake and attain similar TDMI values as those of $\mathrm{OH}$ calves. Although differences in forage intake between $\mathrm{CON}$ and $\mathrm{OH}$ treatments were reported, the variability in concentrate intake (which represents more than $90 \%$ of TDMI) meant that differences in forage intake could not be detected when evaluating TDMI.

Total-tract apparent nutrient digestibility did not differ between treatments 2 wk after weaning (Table 3 ). Results reported herein are in the range previously reported for weaned calves (Terré et al., 2007; Hill et 
Table 2. Performance and feed intake of calves supplemented with oats hay $(\mathrm{OH})$ during the pre- and postweaning periods or not supplemented with oats hay during the preweaning period and supplemented with oats hay during the postweaning period $(\mathrm{CON})$

\begin{tabular}{|c|c|c|c|c|c|c|}
\hline \multirow[b]{2}{*}{ Item } & \multicolumn{2}{|c|}{ Treatment $^{1}$} & \multirow[b]{2}{*}{ SEM } & \multicolumn{3}{|c|}{$P$-value ${ }^{2}$} \\
\hline & $\mathrm{CON}$ & $\mathrm{OH}$ & & $\mathrm{T}$ & $t$ & $\mathrm{~T} \times t$ \\
\hline Initial BW, kg & 39.8 & 40.3 & 0.72 & 0.651 & - & - \\
\hline Final BW at $65 \mathrm{~d}$ of age, $\mathrm{kg}$ & 70.1 & 74.5 & 1.49 & 0.042 & - & - \\
\hline \multicolumn{7}{|l|}{ Preweaning (10 to $51 \mathrm{~d}$ of age) } \\
\hline $\mathrm{ADG}, \mathrm{kg} / \mathrm{d}$ & 0.42 & 0.52 & 0.023 & 0.003 & $<0.001$ & 0.332 \\
\hline \multicolumn{7}{|l|}{ Intake, $\mathrm{kg}$ of $\mathrm{DM} / \mathrm{d}$} \\
\hline Milk replacer & 0.48 & 0.48 & - & - & - & - \\
\hline Starter concentrate & 0.50 & 0.60 & 0.040 & 0.042 & $<0.001$ & 0.173 \\
\hline Forage & - & 0.04 & 0.003 & - & - & - \\
\hline $\mathrm{TDMI}^{3} \mathrm{~kg} / \mathrm{d}$ & 1.07 & 1.21 & 0.041 & 0.006 & $<0.001$ & 0.031 \\
\hline Gain-to-feed ${ }^{4}$ & 0.40 & 0.43 & 0.014 & 0.144 & $<0.001$ & 0.995 \\
\hline DMI, $\%$ of BW & 2.3 & 2.5 & 0.06 & 0.008 & $<0.001$ & 0.195 \\
\hline \multicolumn{7}{|l|}{ Postweaning (52 to $65 \mathrm{~d}$ of age) } \\
\hline $\mathrm{ADG}, \mathrm{kg} / \mathrm{d}$ & 0.89 & 0.91 & 0.039 & 0.781 & 0.206 & 0.890 \\
\hline \multicolumn{7}{|l|}{ Intake, $\mathrm{kg}$ of $\mathrm{DM} / \mathrm{d}$} \\
\hline Starter concentrate & 2.09 & 2.12 & 0.081 & 0.771 & $<0.001$ & 0.068 \\
\hline Forage & 0.09 & 0.15 & 0.031 & 0.017 & 0.011 & 0.657 \\
\hline $\mathrm{TDMI}^{4}$ & 2.16 & 2.25 & 0.088 & 0.487 & $<0.001$ & 0.139 \\
\hline Forage intake, $\%$ of TDMI & 4.8 & 6.7 & 0.49 & 0.013 & 0.264 & 0.913 \\
\hline Gain-to-feed & 0.42 & 0.42 & 0.018 & 0.991 & 0.462 & 0.829 \\
\hline DMI, \% BW & 3.4 & 3.3 & 0.10 & 0.532 & 0.009 & 0.029 \\
\hline
\end{tabular}

${ }^{1} \mathrm{CON}=$ calves fed a concentrate starter without hay supplementation during the preweaning period, and supplemented with oats hay after weaning; $\mathrm{OH}=$ calves fed a concentrate starter supplemented with oats hay throughout the study.

${ }^{2} \mathrm{~T}=$ preweaning forage supplementation effect; $t=$ effect of time; $\mathrm{T} \times t=$ interaction between preweaning forage supplementation and time.

${ }^{3} \mathrm{TDMI}=$ total DMI (milk replacer, starter feed, and forage).

${ }^{4}$ Gain-to-feed $=\mathrm{kg}$ of BW gain $/ \mathrm{kg}$ of TDMI.

al., 2010; Castells et al., 2012). After weaning, the voluntary intake of forage in $\mathrm{CON}$ and $\mathrm{OH}$ animals was 4.8 and $6.7 \%$ of their diet, respectively. These differences did not alter digestibility after weaning, and the previous experience of eating forage did not improve diet digestibility in $\mathrm{OH}$ calves. Digestibility results indicate that young calves fed no forage in the diet during the preweaning period adapted rapidly and were able to digest forage once forage was offered.

Although BW was greater at $65 \mathrm{~d}$ of age in $\mathrm{OH}$ compared with CON calves, these differences disappeared at 10 mo of age (304.8 vs. $306.4 \pm 5.38 ; P=0.84$ ). Several authors have studied long-term effects on growth when applying different treatments during the preweaning period, especially in intensive MR feeding programs. Some previous studies have reported that significant differences in BW are maintained postweaning (RaethKnight et al., 2009; Moallem et al., 2010), but others have not (Terré et al., 2009; Davis Rincker et al., 2011), similar to the present study. In these studies, differences in BW were achieved with different milk-feeding programs, and in Terré et al. (2009) and Davis Rincker et al. (2011), when the milk offer started to decrease, high-fed animals had a slump in their growth that was not observed in the Raeth-Knight et al. (2009) and
Moallem et al. (2010) studies. Furthermore, in Davis Rincker et al. (2011), BW was determined at the onset of puberty, at which time intensively fed calves were 31 d younger than conventionally fed calves. Lower BW at the onset of puberty could be expected in intensively fed calves. In the present study, we did not detect a slump in ADG after weaning, but the ADG of CON calves matched the ADG of $\mathrm{OH}$ calves the week after weaning.

\section{Reproduction}

Three heifers were excluded from the data set: 2 heifers died of pneumonia, and 1 heifer was culled; therefore, data for $28 \mathrm{CON}$ and $29 \mathrm{OH}$ heifers were included for the reproductive data analysis. As heifers were inseminated following age and hip height criteria, differences in age at first breeding were not expected, as observed (Table 4). Similar to the present study, no differences were reported for age at first breeding between calves fed a traditional or an intensive MR feeding program (Terré et al., 2009). Although not significant, conception rate at first service was numerically greater in $\mathrm{OH}$ than in CON calves (Table 4), and the odds of failure at first service for CON were 1.42 times that of 
Table 3. Total-tract apparent nutrient digestibility 2 wk after weaning of calves supplemented with oats hay $(\mathrm{OH})$ during the preand postweaning periods or not supplemented with oats hay during the preweaning period and supplemented with oats hay during the postweaning period $(\mathrm{CON})$

\begin{tabular}{|c|c|c|c|c|}
\hline \multirow[b]{2}{*}{ Digestibility, \% } & \multicolumn{2}{|c|}{ Treatment } & \multirow[b]{2}{*}{$\mathrm{SEM}^{2}$} & \multirow[b]{2}{*}{$P$-value } \\
\hline & $\mathrm{CON}$ & $\mathrm{OH}$ & & \\
\hline DM & 78.3 & 78.4 & 1.29 & 0.96 \\
\hline $\mathrm{OM}$ & 79.2 & 79.4 & 1.24 & 0.93 \\
\hline $\mathrm{CP}$ & 75.2 & 74.8 & 1.55 & 0.86 \\
\hline NDF & 42.3 & 43.5 & 3.03 & 0.80 \\
\hline
\end{tabular}

OH heifers. Similarly, the odds of culling before finishing first lactation for CON heifers was 1.63 times that for $\mathrm{OH}$ heifers, but this difference was not significant (Table 4). The lack of differences could be due to the small number of heifers per treatment, but the results might indicate some benefit of enhancing calf growth before weaning on conception rate and survival during first lactation. Other studies have reported benefits of high nutritional planes early in life on advancing age at puberty (Moallem et al., 2010; Davis Rincker at al., 2011) and decreasing AFC (Raeth-Knight et al., 2009). In the present study, the onset of puberty was not as-

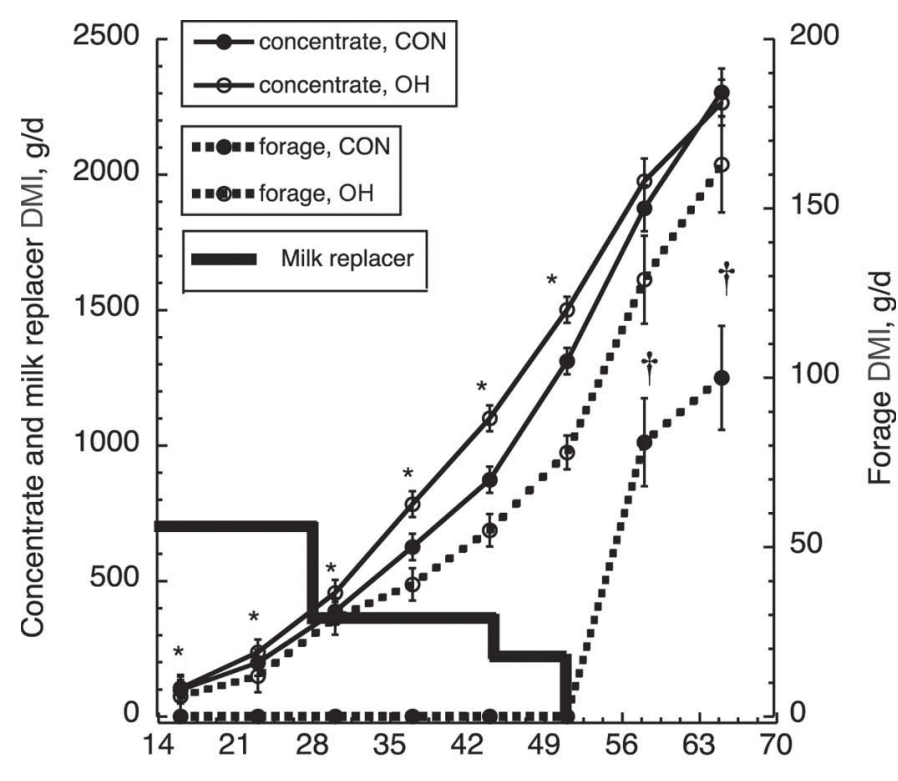

Age, $d$

Figure 1. Evolution of concentrate and forage DMI of calves supplemented with oats hay $(\mathrm{OH})$ during the pre- and postweaning periods or not supplemented with oats hay during the preweaning period and supplemented with oats hay during the postweaning period $(\mathrm{CON}) . *$ denotes significant differences in concentrate intake between treatments at that point; $\dagger$ denotes significant differences in forage intake between treatments at that point; bold continuous line denotes milk replacer intake for both treatments. Error bars denote SEM.
Table 4. Reproductive performance and milk yield at first lactation of heifers that were supplemented with oats hay $(\mathrm{OH})$ during the preand postweaning periods or not supplemented with oats hay during the preweaning period and supplemented with oats hay during the postweaning period $(\mathrm{CON})$

\begin{tabular}{lccrr}
\hline & \multicolumn{2}{c}{ Treatment } & & \\
\cline { 2 - 3 } Item & CON & OH & SEM & $P$-value \\
\hline Age at first service, d & 405.5 & 407.1 & 2.48 & 0.64 \\
Conception rate at first & 53.6 & 62.1 & 38.08 & 0.51 \\
service, \% & & & & \\
Age at fertile AI, d & 422.1 & 426.4 & 6.40 & 0.64 \\
Times bred & 1.6 & 1.7 & 0.17 & 0.85 \\
Age at first calving, d & 702 & 705 & 7.9 & 0.76 \\
Culling rate, \% & 40 & 29 & 38.4 & 0.37 \\
Milk yield at 305 DIM, kg & 9,808 & 9,785 & 280.2 & 0.95 \\
Milk fat, \% & 3.24 & 3.39 & 0.085 & 0.22 \\
Milk protein, \% & 3.26 & 3.29 & 0.041 & 0.66 \\
ECM $^{2}$ at 305 DIM, kg & 8,834 & 9,008 & 225.6 & 0.59 \\
\hline
\end{tabular}

${ }^{1}$ Percentage of heifers not finishing first lactation.

${ }^{2} \mathrm{ECM}$ at $4 \%$ fat and $3.3 \%$ protein.

sessed, and AFC was similar in both groups of animals (Table 4).

\section{Milk Yield}

Milk yield was recorded until 305 DIM, but the resulting data should be considered with caution because only $19 \mathrm{CON}$ and $22 \mathrm{OH}$ cows actually reached 305 DIM. From the power analysis that was performed at $80 \%$ power, and estimating a variation in milk yield of $1,200 \mathrm{~kg}$, differences of $1,000 \mathrm{~kg}$ of milk could be detected as significant with the actual sample size used herein. Differences of $1,000 \mathrm{~kg}$ of milk between CON and $\mathrm{OH}$ were not expected because differences in preweaning ADG between treatments were not extreme enough to attain a 1,000-kg milk yield difference at first lactation, and no differences were observed between treatments in milk yield and milk components (Table 4). However, the linear regression analysis performed between ADG from 17 to $65 \mathrm{~d}$ of age and first-lactation ECM yield at 305 DIM (Figure 2) indicated a positive correlation between these 2 parameters, supporting the importance of ADG early in life with future milk production as previously reported (Bach and Ahedo, 2008; Bach, 2012; Soberon et al., 2012). Soberon et al. (2012) indicated that $22 \%$ of the variation in first-lactation milk production could be explained by growth rate before weaning, similar to our data in the current study. The exact mechanisms responsible for the association between early growth and future productivity are not currently known, but Van Amburgh et al. (2014) noted the importance of feeding energy and protein above maintenance levels early in life and its effects on possible tissue differentiation. 


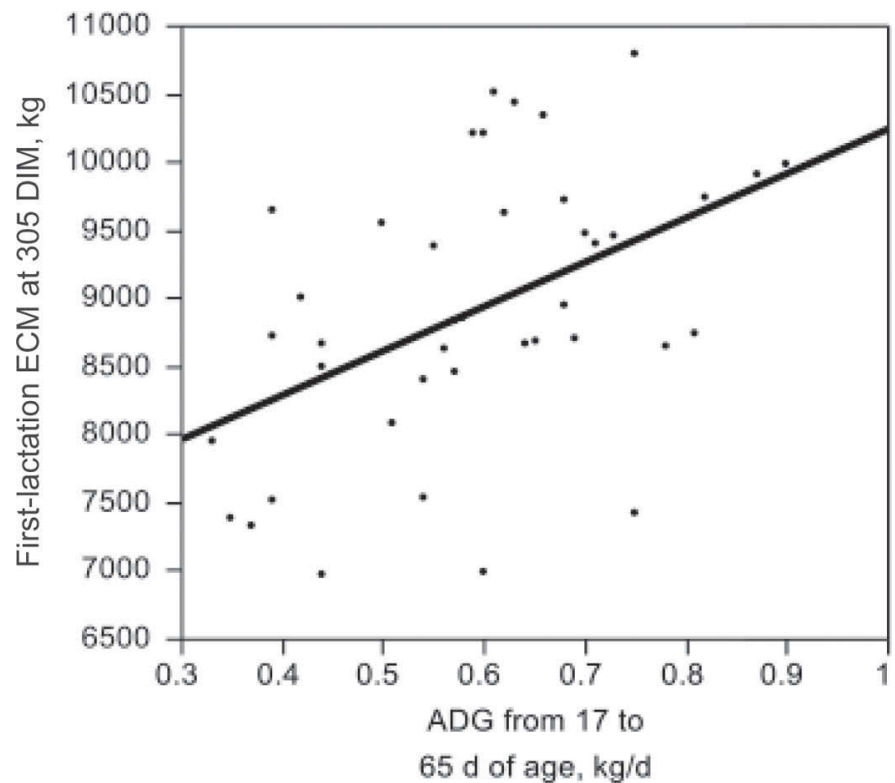

Figure 2. Linear regression between ADG from 17 to $65 \mathrm{~d}$ of age and ECM yield at first lactation at 305 DIM (first-lactation ECM at 305 DIM, $\mathrm{kg}=6,988+3,266 \times \mathrm{ADG}, \mathrm{kg} / \mathrm{d}$ from 17 to $65 \mathrm{~d}$ of age; $\left.\mathrm{R}^{2}=0.22, P=0.0017\right)$.

In conclusion, offering forage to young calves early in life allowed improvements in growth before weaning and could help the transition to mixed diets. However, the improvement in growth was not maintained at 10 mo of age, and no direct benefits in reproductive performance and milk yield were observed later in life. A positive relationship was found between growth rate early in life and future ECM yield during first lactation.

\section{ACKNOWLEDGMENTS}

We thank the Instituto Nacional de Investigación y Tecnología Agraria y Alimentarias (Madrid, Spain) for the partial financial support to conduct this project (RTA2008-00031-00-00). We also thank Carlos Montoro and Pere Ureña from IRTA (Caldes de Montbui, Spain), and Dídac Vieites (from Recria Segle XXI, Vilanant, Spain) for their help with calf management, and Javier Heras from Vether (Vilademuls, Spain) for his help on recording reproduction and milk yield data.

\section{REFERENCES}

AOAC. 1990. Official Methods of Analysis. 15th ed. Association of Official Analytical Chemists, Arlington, VA.

Bach, A. 2012. Nourishing and managing the dam and postnatal calf for optimal lactation, reproduction, and immunity. J. Anim. Sci. 90:1835-1845.
Bach, A., and J. Ahedo. 2008. Record keeping and economics of dairy heifers. Vet. Clin. North Am. Food Anim. Pract. 24:117-138.

Brickell, J. S., N. Bourne, M. M. McGowan, and D. C. Wathes. 2009. Effect of growth and development during the rearing period on the subsequent fertility of nulliparous Holstein-Friesian heifers. Theriogenology 72:408-416.

Castells, Ll., A. Bach, G. Araujo, C. Montoro, and M. Terré. 2012. Effect of different forage sources on performance and feeding behavior of Holstein calves. J. Dairy Sci. 95:286-293.

Castells, Ll., A. Bach, A. Arís, and M. Terré. 2013. Effects of forage provision to young calves on rumen fermentation and development of the gastrointestinal tract. J. Dairy Sci. 96:5226-5236.

Davis Rincker, L. E., M. J. VandeHaar, C. A. Wolf, J. S. Liesman, L. T. Chapin, and M. S. Weber Nielsen. 2011. Effect of intensified feeding of heifer calves on growth, pubertal age, calving age, milk yield, and economics. J. Dairy Sci. 94:3554-3567.

Hill, T. M., H. G. Bateman II, J. M. Aldrich, and R. L. Schlotterbeck. 2010. Effects of milk replacer program on digestion of nutrients in dairy calves. J. Dairy Sci. 93:1105-1115.

Khan, M. A., D. M. Weary, and M. A. G. von Keyerslingk. 2011. Hay intake improves performance and rumen development of calves fed higher quantities of milk. J. Dairy Sci. 94:3547-3553.

Le Cozler, Y., V. Lollivier, P. Lacasse, and C. Disenhaus. 2008. Rearing strategy and optimizing first-calving targets in dairy heifers: A review. Animal 2:1393-1404

Miller-Cushon, E. K., and T. J. DeVries. 2011. Effect of early exposure on diet-selection behavior of dairy calves. J. Dairy Sci. 94:342-350.

Moallem, U., D. Werner, H. Lehrer, M. Zachut, L. Livshitz, S. Yakoby, and A. Shamay. 2010. Long-term effects of ad libitum whole milk prior to weaning and prepubertal protein supplementation on skeletal growth rate and first-lactation milk production. J. Dairy Sci. 93:2639-2650.

Mohd Nor, N., W. Steeneveld, T. van Werven, M. C. Mourits, and H. Hogeveen. 2013. First-calving age and first-lactation milk production on Dutch dairy farms. J. Dairy Sci. 96:981-992.

Raeth-Knight, M., H. Chester-Jones, S. Hayes, J. Linn, R. Larson, D. Ziegler, B. Ziegler, and N. Broadwater. 2009. Impact of conventional or intensive milk replacer programs on Holstein heifer performance through six months of age and during first lactation. J. Dairy Sci. 92:799-809.

Soberon, F., E. Raffrenato, R. W. Everett, and M. E. Van Amburgh. 2012. Preweaning milk replacer intake and effects on long-term productivity of dairy calves. J. Dairy Sci. 95:783-793.

Terré, M., M. Devant, and A. Bach. 2007. Effect of level of milk replacer fed to Holstein calves on performance during the preweaning period and starter digestibility at weaning. Livest. Sci. 110:82-88.

Terré, M., E. Pedrals, A. Dalmau, and A. Bach. 2013. What do preweaned and weaned calves need in the diet: A high fiber content or a forage source? J. Dairy Sci. 96:5217-5225.

Terré, M., C. Tejero, and A. Bach. 2009. Long-term effects on heifer performance of an enhanced-growth feeding programme applied during the preweaning period. J. Dairy Res. 76:331-339.

Thomas, D. B., and C. E. Hinks. 1982. The effect of changing the physical form of roughage on the performance of the early-weaned calf. Anim. Prod. 35:375-384.

Tozer, P. R., and A. J. Heinrichs. 2001. What affects the costs of raising replacement dairy heifers: A multi-component analysis. J. Dairy Sci. 84:1836-1844.

Van Amburgh, M. E., F. Soberon, D. J. Lopez, J. Karszes, and R. W. Everett. 2014. Early life nutrition and management impacts longterm productivity of calves. Pages $35-48$ in Proc. 50th Florida Dairy Production Conference. University of Florida, Gainesville.

Van Soest, P. J., J. B. Robertson, and B. A. Lewis. 1991. Methods for dietary fiber, neutral detergent fiber, and nonstarch polysaccharides in relation to animal nutrition. J. Dairy Sci. 74:3583-3597. 